\title{
Influence of Moisture Content, Loading Rate and Internode Position on the Mechanical Properties of Paddy and Wheat Straw
}

\author{
Mohd. Muzamil*, Indra Mani, Adarsh Kumar and Satish Lande
}

Division of Agricultural Engineering, IARI, New Delhi (110 012), India

\section{Article History}

Manuscript No. AR1469b

Received in $22^{\text {nd }}$ September, 2015

Received in revised form $28^{\text {th }}$ March, 2016

Accepted in final form $30^{\text {th }}$ March, 2016

\section{Correspondence to}

${ }^{*}$ E-mail: muzamil4951@gmail.com

\section{Keywords}

Mechanical properties, paddy straw, wheat straw

\begin{abstract}
The mechanical characteristics of paddy straw and wheat Straw were evaluated in terms of shearing strength, specific shearing energy and cutting force with the change in moisture content, loading rate and inter node position. The parameters were determined at three moisture levels: $1 \%, 7.5 \%$ and $19.5 \% \mathrm{wb}$, three loading rates: 15, 20 and 25 $\mathrm{mm}$. $\mathrm{min}^{-1}$ and three internodes: first $\left(\mathrm{IN}_{1}\right)$, second $\left(\mathrm{IN}_{2}\right)$ and third $\left(\mathrm{IN}_{3}\right)$ position. The results showed that shear strength and specific shearing energy increased with an increase in moisture content and loading rate from first to third internode position. The shear strength of the paddy straw increased from 5.49 to $13.29,6.28$ to 14.69 and 6.98 to $18.26 \mathrm{MPa}$ and for wheat straw 7.59 to $21.76,8.16$ to 23.8 and 8.77 to $24.8 \mathrm{MPa}$ from first to third internode position. The corresponding value for specific shearing energy were 22.13 to $94.71,29.86$ to 115.6 and 35.02 to $158.6 \mathrm{~mJ}$ for paddy straw and 44 to $106.7,49$ to 101.3 and 54.3 to $119.3 \mathrm{~mJ}$ for wheat straw, respectively. The cutting force for paddy and wheat straw varied between 13.4 to $24.6 \mathrm{~N}$ and 14.8 to $27.5 \mathrm{~N}$ for different loading rates and at different inter node positions. Thus, variable load application at different inter node positions can ensure the saving of energy for harvesting and threshing machines.
\end{abstract}

\section{Introduction}

Paddy-wheat systems are critically important for global food security, providing the staple grain supply for about $8 \%$ of the world's population (Timsina and Connor, 2001). Rice and wheat together contribute more than $70 \%$ of the total cereal production with 13.5 mha area under Indo-Gangetic Plain (Ladha et al., 2003). India contributes 9.6 mha (Sharma et al., 2003 ) resulting in the generation of crop residues to the tune of $350 \times 10^{6} \mathrm{~kg}$ year ${ }^{-1}$, with $27 \%$ share of wheat and $51 \%$ of paddy residues (Mandal et al., 2004). The generation of huge agroresidues serves as a reminder to find the suitable methodology for its effective management. The straw is usually employed as feed for animals or burnt in open fields to prepare the land for next crop or enhancement of soil fertility by incorporation into the soil as mulch. However, the commercial utilisation of paddy and wheat straw prompts the necessity of having adequate details about their mechanical properties (Yore et al., 2002).

It is imperative to determine the mechanical properties of paddy and wheat straw to design the equipment for harvesting and threshing effectively. Moreover, it will also help to analyse the behaviour of the product during handling and agricultural processing operations. The studies on the mechanical properties have been carried out with strong emphasis on failure criteria (force, stress and energy) or young's modulus and modulus of rigidity. The mechanical properties were determined by Skubisz (2001) on rape stem, Skubisz (2002) on pea stem, Chen et al. (2004) on hemp stems, Ince et al. (2005) on sunflower stalk and Nazari Galedar et al. (2008a) on alfalfa stems, Tavakoli et al. (2009a) on wheat straw and Tavakoli et al. (2009b) on barely straw. Crop specific parameters like plant anatomy, lodging processes, harvest optimisation, animal nutrition, industrial applications and decomposition pattern in soil can be effectively utilized to characterize the properties of paddy and wheat straw (Annoussamy et al., 2000). The failure of the crop structure and its separation occurs by compression, tension, bending, shearing, density and friction which depends on crop species, variety, stalk diameter, maturity, moisture content and cellular structure (Persson, 1987) and are different at different heights of the plant stalk (Nazari Galedar et al., 2008b). The design of effective machine necessitates the analysis of the properties of the crop like diameter, length, variety, maturity and structure (Bright and Kleis, 1964; Persson, 1987). The chemical composition of paddy and wheat straw also affect the performance of size reducing machines (Agarwal et al., 2008). The cross sectional area and moisture content of the crop 
significantly affect the cutting energy and maximum cutting force requirement of the crop stalks (Prasad and Gupta, 1975).

The shear strength of the alfafa stem internodes using direct shear method varied from 4.08 to $183.5 \mathrm{~kg} \mathrm{~cm}^{-2}$ (Halyk and Hurlbut, 1968). The mean ultimate shear strength for five varieties of winter wheat ranged from 5.39 to $6.98 \mathrm{MPa}$ and $8.53 \mathrm{Mpa}$ for spring wheat at moisture levels ranging from 10 to $15 \%$ wet basis (O'Dogherty et al., 1995). The location of the impact of forces on the internode position and number of stems are significant factors in determining the cutting properties of paddy straw (Summers et al., 2002). A shear box method was used to measure the shear strength of different varieties of foliage materials and it was found that the moisture range of 20 and $35 \%$ corresponds to shear value of 25 to 88 and 59 to $128 \mathrm{MPa}$ (Dernedde, 1970). The mean shear strength value of six varieties of wheat straw ranges between 5.4-8.5 MPa. (O'Dogherty et al., 1995). The experiment on the field grasses reveal that mean shearing stress was $16 \mathrm{MPa}$ and mean shearing energy was $12.0 \mathrm{~mJ} \mathrm{~mm}^{-2}$ (McRandal and McNulty, 1980).

It seems that there is not much published work relating to effects of moisture content, internode position and loading rate on physical and mechanical properties of paddy and wheat straw. Therefore, the study was taken to investigate the effects of moisture content, internode position and loading rate on mechanical properties (shear strength, specific shearing energy and cutting force) of paddy and wheat straw. The physical parameters like diameter, thickness, cross-section area were also considered to check their effect on mechanical properties.

\section{Materials and Methods}

After the harvest, paddy and wheat straw were collected from the experimental fields located at latitude $28.38 \mathrm{~N}, 77.2 \mathrm{E}$ at an altitude of $228.7 \mathrm{~m}$ above sea level. The experiment was conducted in 2014-15 employing the service of random block design. The straw was subjected to manual chopping to divide it into three lengths $(200,140,120 \mathrm{~mm})$ according to the presence of inter node at specific intervals and labelled as $\mathrm{IN}_{1}, \mathrm{IN}_{2}$ and $\mathrm{IN}_{3}$ respectively (Figure 1 and 2). The moisture content was varied as $1 \%, 7.5 \%$ and $19.5 \%$ by the addition of water. The idea behind varying the moisture content was to simulate the conditions due to unseasonal rains at the time of harvest. The moisture content was determined by placing the samples in an oven at $105^{\circ} \mathrm{C}$ for $24 \mathrm{~h}$ and then reweighed (ASABE, 2006). The Leaf blades and sheaths were removed from main stem and straw internodes were separated out according to their position down the ear (Annoussamy et al., 2000). In each inter node, thickness, diameter, area were measured using a digital Vernier Calliper having least count of $0.01 \mathrm{~mm}$ (Table 1and 2).

\subsection{Development of shearing box}

The supple and tensile characteristic of PS necessitates the development of shearing box to overcome its flexibility and ensure easy operability. The square box carries holes of different sizes to accommodate the PS of varying diameter and thickness. The shear box was fixed on the lower resting place on the TA+Di texture analyzer. A sliding plate with blade screwed at the top ensures the deflection of straw internode towards centre. The download motion of the blade through shearing box causes shearing action. The sliding plate was loaded at three loading rates of 15,20 and $25 \mathrm{~mm} \mathrm{~min}^{-1}$. The testing apparatus was similar to the one developed by O'Dogherty et al. (1995), Ince et al. (2005), Nazari Galedar et al. (2008a), Annoussamy et al. (2000); Nazari Galedar et al. (2008b); Tavakoli et al. (2009b); Zareiforoush et al. (2010) to measure the shearing properties of paddy and wheat straw. The shear force was

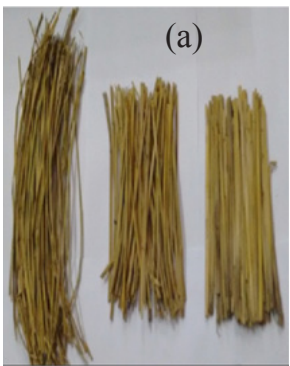

$\begin{array}{lll}\mathrm{IN}_{1} & \mathrm{IN}_{2} & \mathrm{IN}_{3}\end{array}$

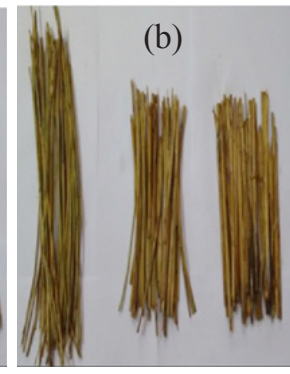

$\mathrm{IN}$
$\mathrm{IN}$
Figure 1: PS inter node position a) $1 \%$; b) $7.5 \%$; c) $19.5 \% \mathrm{MC}$
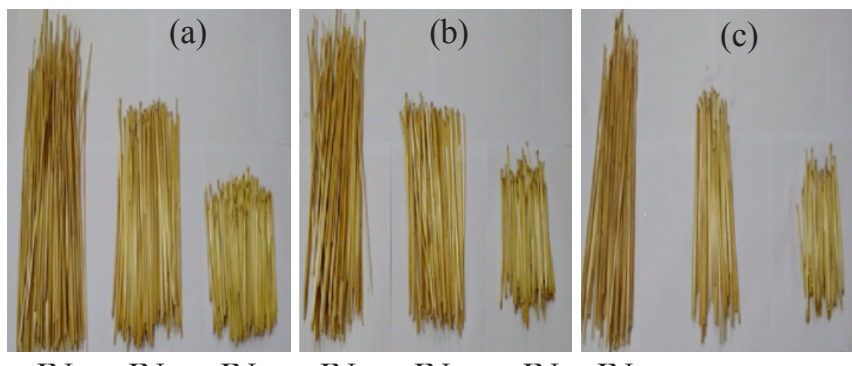

$\begin{array}{lll}\mathrm{IN}_{1} & \mathrm{IN}_{2} & \mathrm{IN}_{3}\end{array}$

$\begin{array}{llllll}\mathrm{IN}_{1} & \mathrm{IN}_{2} & \mathrm{IN}_{3} & \mathrm{IN}_{1} & \mathrm{IN}_{2} & \mathrm{IN}_{3}\end{array}$

Figure 2: WS inter node positions a) $1 \%$; b) $7.5 \%$; c) $19.5 \% \mathrm{MC}$

Table 1: Physical Properties of Paddy straw (PS) at different inter node positions

\begin{tabular}{|c|c|c|c|c|c|c|c|c|c|}
\hline \multirow{3}{*}{$\begin{array}{l}\text { Param- } \\
\text { eters }\end{array}$} & \multicolumn{9}{|c|}{ Paddy Straw } \\
\hline & \multicolumn{3}{|c|}{$1 \% \mathrm{MC}$} & \multicolumn{3}{|c|}{$7.5 \% \mathrm{MC}$} & \multicolumn{3}{|c|}{$19.5 \% \mathrm{MC}$} \\
\hline & $\mathrm{IN}_{1}$ & $\mathrm{IN}_{2}$ & $\mathrm{IN}_{3}$ & $\mathrm{IN}_{1}$ & $\mathrm{IN}_{2}$ & $\mathrm{IN}_{3}$ & $\mathrm{IN}_{1}$ & $\mathrm{IN}_{2}$ & $\mathrm{IN}_{3}$ \\
\hline $\begin{array}{l}\text { Thick- } \\
\text { ness, } \\
\text { mm }\end{array}$ & 5.88 & 8.9 & 10.5 & 6.12 & 6.45 & 10.3 & 6.03 & 7.51 & 11.06 \\
\hline $\begin{array}{l}\text { Diam- } \\
\text { eter, } \\
\mathrm{mm}\end{array}$ & 2.42 & 5.5 & 6.02 & 2.60 & 3.1 & 3.9 & 2.27 & 4.38 & 4.89 \\
\hline $\begin{array}{l}\text { X-sec- } \\
\text { tional } \\
\text { area, } \\
\mathrm{mm}^{2}\end{array}$ & 4.61 & 24.1 & 28.4 & 5.3 & 7.6 & 11.9 & 4.04 & 15 & 18.7 \\
\hline
\end{tabular}




\begin{tabular}{|c|c|c|c|c|c|c|c|c|c|}
\hline \multirow{3}{*}{$\begin{array}{l}\text { Param- } \\
\text { eters }\end{array}$} & \multicolumn{9}{|c|}{ Wheat Straw } \\
\hline & \multicolumn{3}{|c|}{$1 \% \mathrm{MC}$} & \multicolumn{3}{|c|}{$7.5 \% \mathrm{MC}$} & \multicolumn{3}{|c|}{$19.5 \% \mathrm{MC}$} \\
\hline & $\mathrm{IN}_{1}$ & $\mathrm{IN}_{2}$ & $\overline{\mathrm{IN}_{3}}$ & $\overline{\mathrm{IN}_{1}}$ & $\mathrm{IN}_{2}$ & $\overline{\mathrm{IN}_{3}}$ & $\overline{\mathrm{IN}_{1}}$ & $\mathrm{IN}_{2}$ & $\mathrm{IN}_{3}$ \\
\hline $\begin{array}{l}\text { Thick- } \\
\text { ness, } \\
\text { mm }\end{array}$ & 5.43 & 8.5 & 7.46 & 7.10 & 6.78 & 8.46 & 7.03 & 8.62 & 6.88 \\
\hline $\begin{array}{l}\text { Diam- } \\
\text { eter, } \\
\mathrm{mm}\end{array}$ & 2.80 & 3.96 & 4.51 & 2.79 & 4.24 & 4.27 & 2.96 & 3.48 & 4.59 \\
\hline $\begin{array}{l}\mathrm{X} \text {-sec- } \\
\text { tional } \\
\text { area, } \\
\mathrm{mm}^{2}\end{array}$ & 6.15 & 12.3 & 15.9 & 6.1 & 14.1 & 14.3 & 6.8 & 9.5 & 16.5 \\
\hline
\end{tabular}

measured by S-type load cell and force-distance relation was recorded upto the failure of straw in TA+Di Texture Analyzer. The shear failure stress (ultimate shear strength) of the specimen was calculated from the equation below (Tavakoli et al., 2008; Tavakoli et al., 2009b; Zareiforoush et al., 2010).

Where, $\boldsymbol{\tau}_{\mathrm{s}}=$ shear strength, MPa; Fs=shear force at failure, N;

$$
\tau \mathrm{s}=\frac{\mathrm{Fs}}{\mathrm{A}}
$$

$A=$ wall area of the specimen at the failure cross-section, $\mathrm{mm}^{2}$

\subsection{Specific shearing energy}

The application of the force on the straw causes deflection to the point of failure stress, where breakdown of the individual particles causes its layers to get detached. The specific shearing energy was determined from force displacement curve by integrating the area from initial level to the point where failure occurs (Chen et al., 2004; Nazari Galedar et al., 2008; Zareiforoush et al., 2010) using a lab texture pro computer program of TA+Di Texture Analyzer and data acquisition system.

\subsection{Cutting force}

The Warner-Bratzler blade was used for determining the cutting force requirement of PS and WS. The blade was held in its place by two locking screws. A central slot allows free movement of the blade to limit friction during analysis.

\section{Results and Discussion}

\subsection{Shearing strength}

The shear strength increased with an increase in moisture content and loading rate from $1 \mathrm{~N}_{1}$ to $1 \mathrm{~N}_{3}$ of RS and WS. The Shear strength of $1 \%$ PS varies between 5.49 to $8.22,6.95$ to 10.21 and 9.54 to $13.29 \mathrm{MPa}$ under loading rate of $15 \mathrm{~mm}$. $\mathrm{min}^{-1}, 20 \mathrm{~mm} \mathrm{~min}{ }^{-1}$ and $25 \mathrm{~mm}$. $\mathrm{min}^{-1}$ for $\mathrm{IN}_{1}, \mathrm{IN}_{2}$ and $\mathrm{IN}_{3}$ respectively (Figure 3). The corresponding values for the 1\% WS ranged from 7.59 to $18.5,10.5$ to 20.3 and 13.2 to 21.76 MPa owing to its lower flexibility in comparison to $1 \%$ paddy straw. The moisture content, inter node position and loading rate along with their interactions had significant effect on the shearing strength at $5 \%$ probability level. The peak value of shear strength occurs at $19.5 \%$ moisture content at $25 \mathrm{~mm} \mathrm{~min}^{-1}$ loading rate for both paddy and wheat straw. The uppermost value of shear strength (24.8 MPa) occurs at $\mathrm{IN}_{3}$ for WS and 18.26 MPa for RS and least value were associated with $15 \mathrm{~mm}$. $\mathrm{min}^{-1}$ at $\mathrm{IN}_{1}$. The average shearing strength value of RS and WS varies between 5.49 to $18.26 \mathrm{MPa}$ and 7.59 to $24.8 \mathrm{MPa}$ which compliance with the results obtained by Zareiforoush et al. (2010). Moreover, shear strength increases from $\mathrm{IN}_{1}$ to $\mathrm{IN}_{3}$ for both RS and WS, similar to the results obtained by Tavakoli et al. (2009a). The average shearing strength of 7 to $22 \mathrm{MPa}$ of wheat straw (Kushaha et al., 1983) for moisture content ranging from 5 to $30 \%$ confirms the validity of the results obtained in this study.

\subsection{Specific shearing energy}

The specific shearing energy showed an increasing trend with the increase in moisture content and loading rates from $\mathrm{IN}_{1}$ to $\mathrm{IN}_{3}$. The contrast in specific shearing energy with the variation in the moisture content was also found by Chen et al. (2004) for hemp stalk and Nazari Galedar et al. (2008a) for alfalfa stem. The shearing energy for $1 \%$ RS varied from 22.13 to $86.35,26.39$ to 89.67 and 27.51 and $94.71 \mathrm{~mJ}^{\text {from }} \mathrm{IN}_{1}$ to $\mathrm{IN}_{3}$ at 15,20 and $25 \mathrm{~mm} \mathrm{~min}^{-1}$ loading rates. For $1 \% \mathrm{WS}$, the values changed from 44 to $69.48,57.21$ to 79.9 and 67.82 to
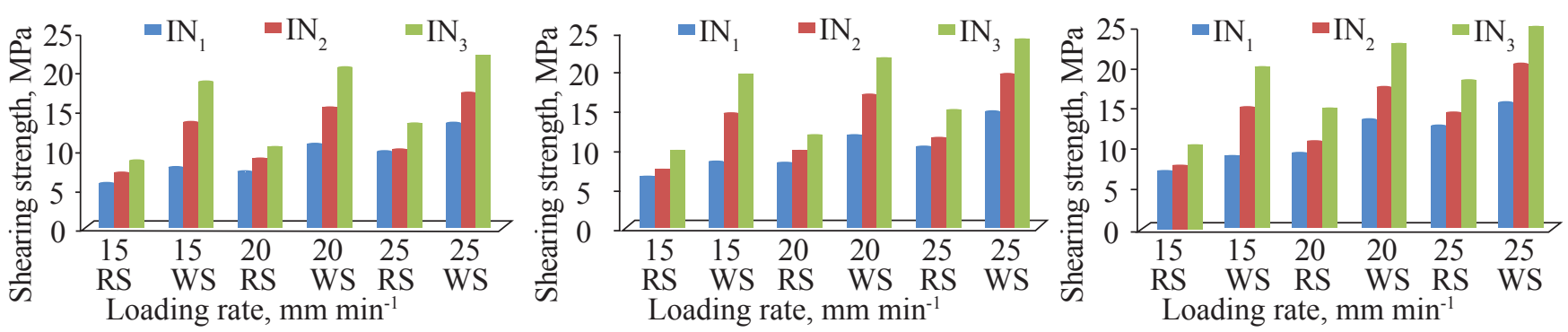

Figure 3: Shearing strength of PS and WS at different inter node positions and loading rates (a) $1 \% \mathrm{MC}$ (b) $7.5 \% \mathrm{MC}$ (c) $19.5 \% \mathrm{MC}$ 
106.7 $\mathrm{mJ}_{\text {from }} \mathrm{IN}_{1}$ to $\mathrm{IN}_{3}$ at 15,20 and $25 \mathrm{~mm} \mathrm{~min}^{-1}$ loading rates respectively (Figure 4 ). With the increase in moisture and loading rates, the shearing energy starts to escalate due to viscous damping effect of the moisture, similar to the one reported by Persson (1987). Statistical analysis also proved that shearing energy were significantly $(p<0.05)$ affected by

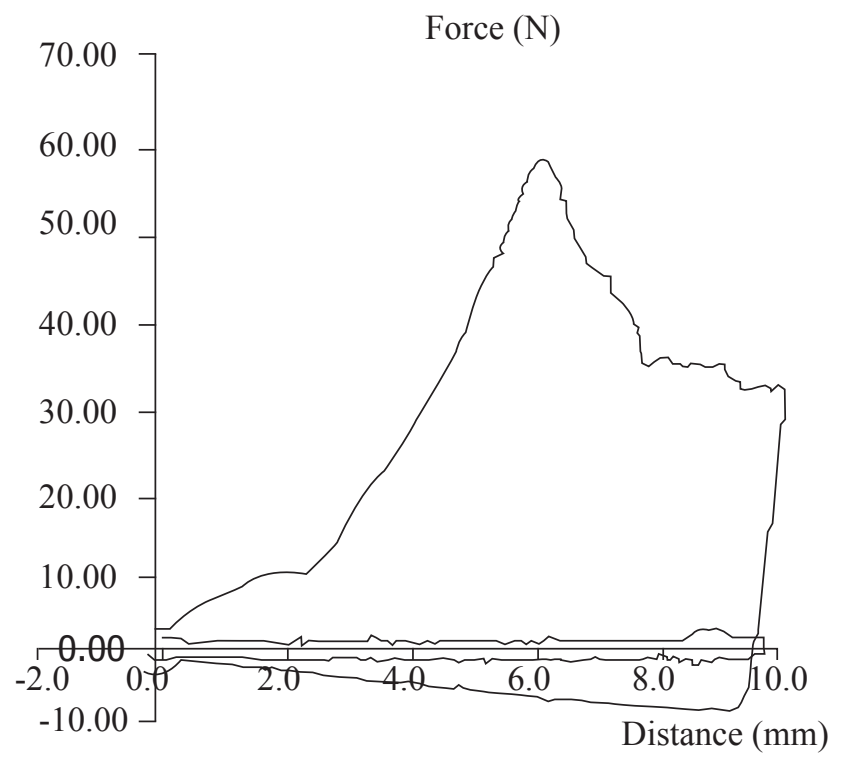

moisture content at 5\% probability level. The shearing energy for RS at $19.5 \%$ moisture content varied from 35.02 to 115.01 ,

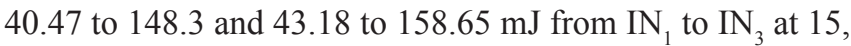
20 and $25 \mathrm{~mm} \mathrm{~min}^{-1}$ loading rate while for WS 54.3 to 78.2 , 70.2 to 92.5 and 81.4 to $119.3 \mathrm{~mJ}$ respectively. The increase in specific shearing energy from $\mathrm{IN}_{1}$ to $\mathrm{IN}_{3}$ was mainly due to accumulation of more mature fibres in the stem (Once et al., 2005).

\subsection{Variation in cutting force}

The cutting force for $1 \%$ moisture content PS changed from 13.4 to $16.38,15.5$ to 17.2 and 17.34 to $18.9 \mathrm{~N}$ and for $1 \%$ moisture content WS as 14.8 to $17.6,17.4$ to 19.7 and 19.3 to $22.3 \mathrm{~N}_{\text {from }} \mathrm{IN}_{1}$ to $\mathrm{IN}_{3}$ at 15,20 and $25 \mathrm{~mm} \mathrm{~min}^{-1}$ loading rate. Overall, the cutting force decreases with the increase in loading rate. Lowest cutting force occurs at first inter node position $\left(\mathrm{IN}_{1}\right)$. Similar results were found by Annoussamy et al. (2000) for wheat straw and Nazari Galedar et al. (2008) for alfafa stem. The inter node positions had significant $(p<0.05)$ effect on the amount of cutting force of RS and WS. At moisture content of $19.5 \%$, the cutting force of RS varied as 15.3 to $18.4,18.1$ to 21.9 and 23.6 to $24.6 \mathrm{~N}$ while for WS 19.6 to $22.5,20.78$ to 23.87 and 23.7 to $27.49 \mathrm{~N}$ respectively (Figure 5).

Figure 3: Force distance curve

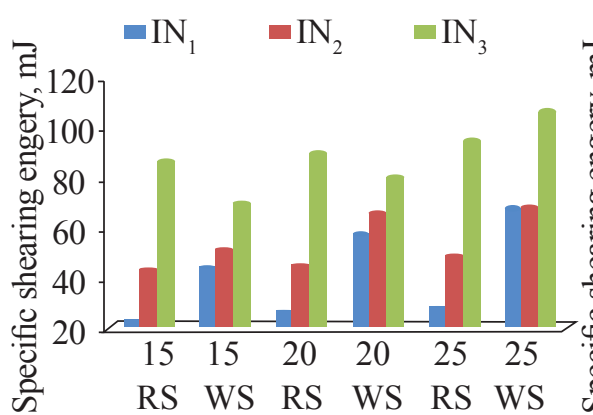

Loading rate, $\mathrm{mm} \mathrm{min}^{-1}$

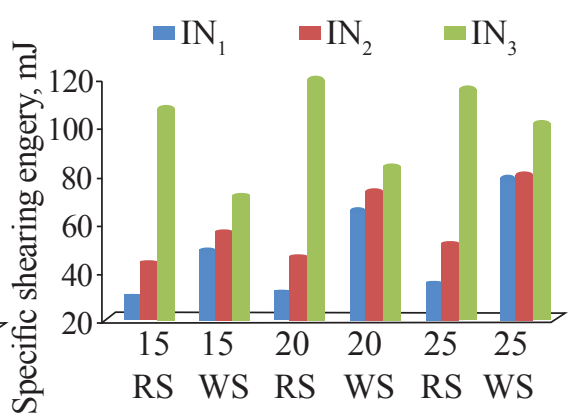

Loading rate, $\mathrm{mm} \mathrm{min}^{-1}$

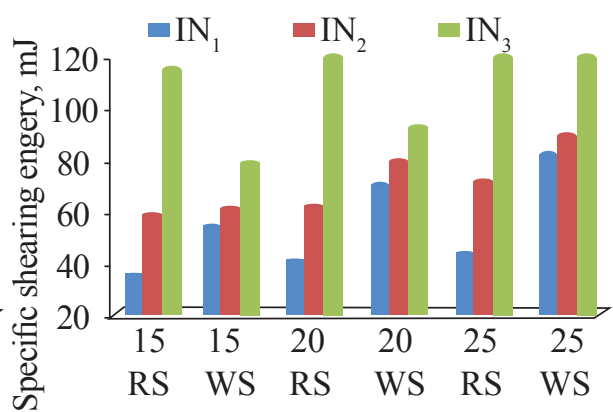

Loading rate, $\mathrm{mm} \mathrm{min}^{-1}$

Figure 4: Specific Shearing Energy of PS and WS at different inter node positions and loading rates (a) 1\% MC (b) $7.5 \%$ MC (c) $19.5 \% \mathrm{MC}$
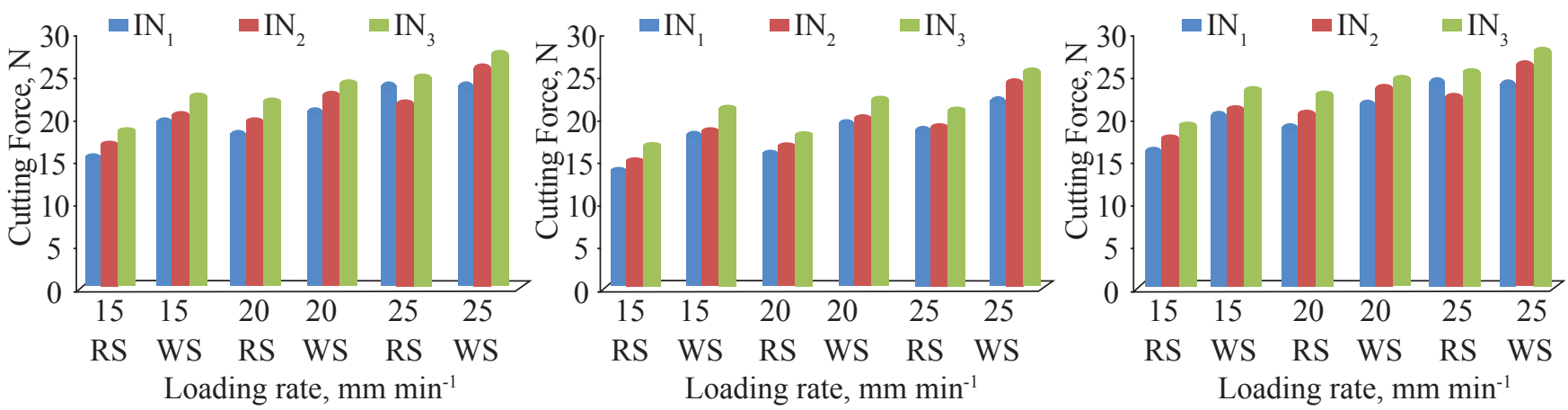

Figure 5: Variation in Cutting Force of RS and WS at different inter node positions and loading rates (a) $1 \%$ MC (b) $7.5 \%$ MC (c) $19.5 \% \mathrm{MC}$ 


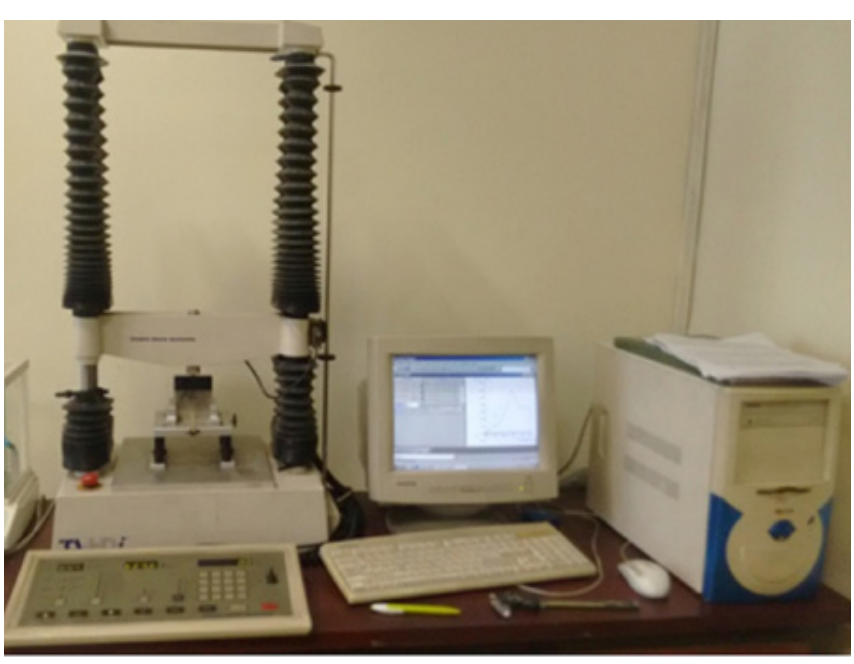

Figure 4: Experimental apparatues

\section{Conclusion}

The increase in $\mathrm{MC}$ and loading rate from 1-19.5\% and $15-25$ $\mathrm{mm}$. $\mathrm{min}^{-1}$ increased shear strength from 5.49 to $18.26 \mathrm{MPa}$ for PS and 7.59 to $24.8 \mathrm{MPa}$ for $\mathrm{WS}$ from $\mathrm{IN}_{1}$ to $\mathrm{IN}_{3}$ position. The maximum specific shearing energy of $158.65 \mathrm{~mJ}$ for PS and $119.3 \mathrm{~mJ}$ for WS necessitates recommending lower moisture content and higher loading rate as optimum conditions to minimize the energy requirement for shearing strength, specific shearing energy and cutting force.

\section{References}

Agarwal, S., Trivedi, R.C., Sengupta, B., 2008. Air pollution due to burning of agricultural residue. Indian Journal of Air Pollution Control 8(1), 51-59.

Annoussamy, M., Richard, G., Recous, S., Guerif J., 2000. Change in mechanical properties of wheat straw due to decomposition and moisture. Applied Engineering in Agriculture 16(6), 657-664.

ASABE standards, 2006. S358.2: 1:1 Measurement-Forages. $52^{\text {nd }}$ ed. American Society of Agricultural and Biological Engineers, St Joseph MI.

Bright, R.E., Kleis, R.W., 1964. Mass shear strength of haylage. Transactions of the American Society of Agricultural Engineers 7(2), 100-101.

Chen, Y., Gratton, J.L., Liu, J., 2004. Power requirements of hemp cutting and conditioning. Biosystem Engineering 87(4), 417-424.

Dernedde, W., 1970. Die technologischeneigenschaften von gras und dereneinfluss den schneidvorgang. Zerkleinern Von HalmfutterLandbForseh-Völkenrode. Sondern 8, 53-57.

Halyk, R.M., Hurlbut, L.W., 1968. Tensile and Shear Strength Characteristics of Alfalfa Stems. Transactions of American Society of Agricultural Engineers 11(2),
$256-257$.

Ince, A., Ugurluay, S., Guzel, E., Ozcan, M.T., 2005. Bending and shearing characteristics of sunflower stalk residue. Biosystem Engineering 92(2), 175-181.

Kushaha, R.L., Vashnav, A.S., Zoerb, G.C., 1983. Shear strength of wheat straw. Canadian Agricultural Engineering 25(2), 163-166.

Ladha, J.K., Hill, J.E., Duxbury, J.D., Gupta, R.K., Buresh, R.J. (Eds), 2003. Improving the productivity and sustainability of rice-wheat systems: issues and impact. American Society of Agronomy Special Publication 65. Madison, Wis. (USA): ASA, CSSA, SSSA. P. 211

Mandal, K.G., Misra, A.K., Hati, K.M., Bandyopadhyay, K.K., Ghosh, P.K., Mohanty, M., 2004. Rice residue management options and effects on soil properties and crop productivity. Food, Agriculture and Environment 2, 224-231.

McRandal, D.M., McNulty, P.B., 1980. Mechanical and physical properties of grasses. Transactions of American Society of Agricultural Engineers 23(4), 816-821.

Nazari Galedar, M., Jafari, A., Mohtasebi, S.S., Tabatabaeefar, A., Sharifi, A., O’Dogherty, M.J., Rafee, S., Richard, G., 2008. Effects of moisture content and level in the crop on the engineering properties of alfalfa stems. Biosystem Engineering 101(2), 199-208.

Nazari Galedar, M., Tabatabaeefar, A., Jafari, A., Sharifi, A., O’Dogherty, M.J., Rafee, S., Richard, G., 2008a. Effects of moisture content and level in the crop on the engineering properties of alfalfa stems. Biosystem Engineering 101(2), 199-208.

Nazari Galedar, M., Tabatabaeefar, A., Jafari, A., Sharifi, A., Rafee, S., 2008b. Bending and shearing characteristics of alfalfa stems. Agricultural Engineering International, CIGR e-journal, Manuscript FP 08 001, X.

O’Dogherty, M.J., Huber, J.A., Dyson, J., Matshal, C.J., 1995. A Study of the Physical and Mechanical Properties of Paddy Stems. Journal of Agricultural Engineering Research 62, 133-142.

Persson, S., 1987. Mechanics of Cutting Plant Material. ASAE Press, St. Joseph, MI, USA. 288 P.

Prasad, J., Gupta, C.B., 1975. Mechanical properties of maize stalks as related to harvesting. Journal of Agricultural Engineering Research 20(1), 79-87.

Sharma, S.K., Subba Rao, A.V.M., Murari, K., Sharma, G.C., 2003. Atlas of rice-wheat cropping system in Indo Gangetic plains. Project Directorate for Cropping System Research, Modipuram, India.

Skubisz, G., 2001. Development of studies on the mechanical properties of winter rape stems. International Agrophysics 15, 197-2001.

Skubisz, G., 2002. Method for the determination of the mechanical properties of pea stems. International 
Agrophysics 16, 73-77.

Skubisz, G., Kravtsova, T.I., Velikanov, L.P., 2007. Analysis of the strength properties of pea stems. International Agrophysics 21, 189-197.

Summers, M.D., Jenkins, B.M., Yore, M.W., 2002. Cutting Properties of Rice Stems. Paper No. 026254. ASAE meeting presentation.

Tavakoli, H., Mohtasebi, S.S., Jafari, A., 2009a. Physical and mechanical properties of wheat straw as influenced by moisture content. International Agrophysics 23(2), 175-181.

Tavakoli, H., Mohtasebi, S.S., Jafari, A., Nazari Galedar, M., 2009b. Some engineering properties of barley straw. Applied Engineering in Agriculture 25(4), 627-633.

Tavakoli, S.S., Mohtasebi, A., Jafari, A., 2008. A comparison of mechanical properties of wheat and barley straw. Agricultural engineering international: the CIGR e-journal. Manuscript number CE 12 002. Vol. 10. December, 2008.

Timsina, J., Connor, D.J., 2001. Productivity and management of rice-wheat cropping systems: issue and challenges. Field Crops Research 69, 93-132.

Yore, M.W., Jenkins, B.M., Summers, M.D., 2002. Cutting properties of rice straw. ASAE. Annual International Meeting/CIGR XV the World Congress. USA, 28-31 July, 1-9.

Zareiforoush, H., Mohtasebi, S.S., Tavakoli, H., Alizadeh, M.R., 2010. Effect of loading rate on mechanical properties of rice (Oryza sativa L.) straw. Australian Journal of Crop Science 4(3), 190-193. 